\title{
Bibliography
}

Adhikari, B., 2012. Sikkim: The Wounds of History, Siliguri: Biraj Adhikari.

Adhikari, D., 2007. Reengineering of Local Governance in the Post-Conflict Situation in Nepal. Contribution to Nepalese Studies, 34(2), pp.139-163.

Aiyar, S., 2003. India' socio-economic faultline- a review. In B. Debroy \& L. Bhandari, eds. District-level Deprivation in the New Millenium. New Delhi: Konark Publisher.

Ake, C., 1995. Political elites and the process of Democratisation in Africa. In J. Hippler, ed.Democratization of Disempowerment:the problem of democracy in the Third World. London: Pluto Press , pp. 70-89.

Amatya, S., 2004. Rana Rule in Nepal, New Delhi: Nirala Publications.

Arora, V., 2006. Roots and Route of Secularism in Sikkim. Economic and Political Weekly, 41(38), pp.4063-4071.

Arora, V., 2006. The Forest of Symbols Embodied in the Tholung Sacred Landscape of North Sikkim, India. Conservation and Society, 4(1), pp.55-83.

Bagahi, S.. \& Danda, A.., 1982. NE-BU-LA: A Movement for Regional Solidarity. In S. K. Singh, ed. Tribal Movements in India. New Delhi: Manohar, pp. 339-348.

Banerjee, A. et al., 2002. Stratergy for Economic Reform in West Bengal. Economic and Political Weekly, 37(41), pp.4203-4218.

Banerji, S., 1986. Gorkhaland Agitation-Cynical Politicking. Economic and Political Weekly, 21(40), pp.1770-1721.

Bangdel, L., 1947. Muluk Bahira, Kathamandu: Ratna Pustak Bhandar.

Baral, B. \& Tigela, K., 2008. Limbuanko Rajniti: Itihas, Bartaman ra Bhavishya, Dharan: Book Club Prakashan.

Baral, L.R., 1995. The 1994 Nepal Elections: Emerging Trends in Party Politics. Asian Survey, 35(5), pp.426-440.

Barth, F. ed., 1969. Ethnic Groups and Boundaries: The Social Organization of Cultural Difference, London: Allen and Unwin.

Baud, M. \& Van Van Schendel, W., 1997. Towards a Comparative History of Borderlands. Journal of World History, 8(2), 211-242.

Bentley, J., 2007. Change and cultural revival in a mountain community of Sikkim. Bulletin of Tibetology, 43(1-2), pp.59-79.

Besky, S., 2008. Can a Plantation be Fair? Paradoxes and possibilities in fair trade Darjeeling tea certification. Anthropology of Work Review, 29(1), pp.1-9. 
Beissinger, M.R., 2008. A new look at ethnicity and democratization. Journal of Democracy, 19(3), pp.85-97.

Bhattachan, K., 2008. Minorities and Indigenous Peoples of Nepal, Kathmandu: National Coalition Against Racial Discrimination.

Bhattachan, K.B., 1995. Ethnopolitics and Ethnodevelopment: An Emerging Pluralism in Nepal. In D. Kumar, ed. State Leadership and Politics in Nepal. Kathmandu: Centre for Nepal and Asian Studies (CNAS), pp. 124-147.

Bhattarai, G.R., 1988. Muglan 3rd ed., Dhankuta: Rajeshvar Prakashan.

Bhowmik, S.K., 1996. Tea Plantation Workers in West Bengal. In S. K. Bhowmik, V. Xaxa, \& M. . Kalam, eds. Tea Plantation Labour in India. New Delhi: Friedrich Ebert Stiftung, pp. 43-80.

Bhowmik, S.K., 1980. The Plantation as a Social System. Economic and Political Weekly, 15(36), pp.1524-1527.

Bijoy, C., Gopalakrishnan, S. \& Khanna, S., 2010. India and the Rights of Indigenous Peoples; Constituional, Legislative and Administrative Provisions Concerning Indigenous and Tribal Peoples in India and their Relation to International Law on Indigenous People, Thailand: Asia Indigenous Peoples Pact.

Bomjan, D.S., 2008. Darjeeling-Dooars People and Place under Bengal's Neo-Colonial Rule, Darjeeling: Bikash Jana Sahitya Kensra.

Booth, C.L., 2011. Ph.D Thesis.These People Deprived of This Country: Language and the Politics of Belonging among Indians of Nepali Descent. New Jersey: Rutger University.

Bottomore, T., 1966. Elites and Society 2nd ed., Harmondsworth: Penguin.

Brown, D., 1994. State and Ethnic Politics in South-East Asia, London: Routledge.

Brown, T.L., 1996. The challenge to Democracy in Nepal: a Political History, London: Routledge.

Brubaker, R. \& Cooper, F., 2000. Beyond “identity”. Theory and Society, (29), pp.1-47..

Burghart, R, 1984. The Formation of the Concept of Nation-State in Nepal. Journal of Asian Studies, 44(11), pp.101-125.

Burghart, Richard, 1996. Conditions of Listening: Essays on Religion, History, and Politics in South Asia, New Delhi: Oxford University Press.

Caddell, M., 2007. Education and Change: A Historical Perspective on Schooling, Dewvelopment and the Nepali NAtion-State. In K. Krishna \& J. Oesterheld, eds. Education and Social Change in South Asia. New Delhi: Orient Longman, pp. 251-284.

Campbell, J.R. \& Rew, A. eds., 1999. Identity and Affect, London: Pluto Press. 
Caplan, L., 1975. Administration and Politics in a Nepalese Town: The Study of a District and its Environs, London: Oxford University Press.

Caplan, L., 1991. "Bravest of the Brave": Representations of "The Gurkha" in British Military Writings. Modern Asian Studies, 25(3), pp.571-97.

Caplan, L., 1970. Land and Social Change in East Nepal, London: Routledge.

Carter, B. \& Fenton, S., 2009. Not Thinking Ethnicity: A Critique of the Ethnicity Paradigm in an Over-Ethnicised Sociology. Journal for the Theory of Social Behaviour, 40(1), pp.1-18.

Cerulo, K.A., 1997. Identity Construction: New Issues, New Directions. Annual Review of Sociology, 23, pp.385-409.

Chakaravarthi, K.., 1994. Government and Politics in Sikkim. In M. Lama, ed. Sikkim: Society, Polity, Economy, Environment. New Delhi: Indus Publishing Company, p. 92-=113.

Chakrabarti, A., 2010. A Critical Review of Agrarian Reforms in Sikkim. Economic and Political Weekly, XLV(5), pp.23-26.

Chakrabarti, A., 2012. From Share Tenancy to Agrarian Reform: Sikkim in Perspective. In M. Yasin \& D. Chhetri, eds. Politics, Society and Development: Insights from Sikkim. New Delhi: Kalpaz Publications, pp. 87-99.

Chakraborty, C., 2008. The Gorkhaland Movement: An Enquiry into the Social Background of the Crisis: Contested Cultural Identity. In R. Bhadra \& M. Bhadra, eds. Ethnicity, Movement and Social Structure. Jaipur: Rawat Publications, pp. 287-308.

Chakraborty, J., 2000. Elections and Casteist Politics. Economic and Political Weekly, 35(43/44), pp.3805-3807.

Chalmers, R., 2003. The Quest for Ekrupata:Unity, Uniformity and the Dileanation of the Nepali Community in Darjeeling. In A. C. Sinha \& T. . Subba, eds. The Nepalis in North-east India: A Community in Search of Indian Identity. New Delhi: Indus Publishing House, pp. 339-359.

Chamlers, R., 2003. "We Nepalis"" Language, Literature and the formation of a Nepali public sphere in India 1914-1940. Ph.D Thesis. School of Oriental and African Studies, University of London.

Chandra, K., 2005. Ethnic Parties and Democratic Stability. Perspectives on Politics, 3(2), pp.235-252.

Chandra, K., 2000. The Transformation of Ethnic Politics in India: The Decline of the Congress and the Rise of Bahujan Samaj Party in Hoshiarpur. The Journal of Asian Studies, 59(1), pp.26-61.

Chatterjee, P., 2001. A Time for Tea: Women, Labor, and Post/Colonial Politics on an Indian Plantation, Durham: Duke University Press.

Chemjong, I.S., 2003. History and Culture of Kirat People 4th ed., Kathmandu: Kirat Yakthung Chumlung.

Chemjong, I.S., 1948. Kirat Itihas, Kahmandu: Ratna Pustak Bhandar. 
Chettri, U., 1999. Nepali Sahityako Vikasma Sikkimka Sanghsanstha haru ko Yogdan, Gangtok: Sikkim Sahitya Parishad.

Chhetri, H.., 2008. Panchayati Raj System and Development Planning: The Case of Sikkim, Jaipur: Rawat Publications.

Chettri, M., 2013. Choosing the Gorkha: At the Crossroads of Ethnicity and Class in the Darjeeling Hills. Asian Ethnicity, 14 (3) pp. 293-308.

Chetttri, M, 2015. Engaging the state: Ethnic Patronage and Cultural Politics in the eastern Himalayan Borderland. South Asia: Journal of South Asian Studies, DOI 10.1080/00856401.2015.1070236

Clement,N., Ganster, P. \& Sweedler,A.2005. Environment, development and security in border regions. In P.Ganster \& D. Lorey. eds., Borders and Border Politics in a Globalizing World, Lanham:SR Books, pp.199-236.

Comaroff, J.L. \& Comaroff, J., 2009. Ethnicity, Inc, Chicago: University of Chicago Press.

Cowan, J.., Dembour, M.-B. \& Wilson, R., 2001. Introduction. In Culture and Rights: Anthropological Perspectives. Cambridge: Cambridge University Press, pp. 1-30.

Dafflon, B., 2009. Strengthening Gram Panchayat: Planning and Budgeting in Sikkim, Indo-Swiss Mission to Sikkim.

Dangal, R., 2005. Administrative Culture in Nepal: Does It Reflect the Dominant Socio-Cultural Values of Nepal. Norway: University of Bergen. Available at:

http://www.ub.uib.no/elpub/2005/h/701002/Masteroppgave.pdf (accessed:27/07/2012).

Das, B., 1983. The Sikkim Saga, New Delhi: Vikas Publishing House.

Dasgupta, A., 1999. Ethnic Problems and Movements for Autonomy in Darjeeling. Social Scientist, 27(11/12), pp.47-68.

Dash, A.J., 1947. Bengal District Gazetteer, Alipore: Bengal Government Press.

Datta, T.K., 2010. Advantages, constraints and key success factors in establishing origin and tradition-linked quality signs: the case of Darjeeling Tea, India, Indian Institute of Management, Kolkata: Food and Agriculture Organisation of the United Nations. Available at: http://www.foodquality-origin.org/documents/DarjeelingTea.pdf (accessed: 24/10/20100.

Debroy, B. \& Bhandari, L., 2003. District-level deprivation in the new millennium, New Delhi: Konark Publishers.

Dekens, J., 2005. Livelihood Change and Resilience Building: A Village Study from the Darjeeling Hills, Eastern Himalaya, India. Thesis. Canada: University of Manitoba. Available at: http://www.umanitoba.ca/institutes/natural_resources/canadaresearchchair/thesis/jdekens\%20ma sters\%20thesis\%202005.pdf (accessed: 24/10/2010). 
Department of Economics, Statisttics, Monitoring and Evaluation, 2006. State Socio-Economic Census 2006, Gangtok, Sikkim: Government of Sikkim.

Dhakal, R., 2009. The Urge to Belong: An Identity in Waiting. In Tanka Bahadur Subba et al., eds. Indian Nepalis: Issues and Perspectives. New Delhi: Concept Publishing Company, pp. 148-167.

Dixit, K.M., 1997. Bahadur = Kancha = Gorkha. Himal Magazine, 10(1), p.15.

Donnan, H. and Wilson, T.M., 1994. Border approaches: anthropological perspectives on frontiers. University Press of America..

Dorjee, P.W., 2012. Some Issues in the early British Construction of Sikkimese History. In A. Balikci-Denjongpa \& A. McKay, eds. Buddhist Himalaya: Studies in Religion, History and Culture. Gangtok: Namgyal Institute of Tibetotology, pp. 63-72.

Dutta, S., 1998. Identities and the Indian State: An Overview. Third World Quarterly, 19(3), pp.411-434.

Edingo, D.B., 2007. A Pragmatic Glimpse at Limbu Mundhum. Contributions to Nepalese Studies, 34(2), pp.165-182.

Eisinger, P.K., 1973. Conditions of Protest Behavior in American Cities. The American Political Science Review, 67(1), pp.11-28.

Elster, J., 1989. Nuts and Bolts for the Social Sciences, Cambridge: Cambridge University Press.

English, R., 1982. Gorkhali and Kiranti: Political Economy in the Eastern Hills of Nepal. Ann Arbor: New School of Social Research.

Enloe, C.H., 1980. Ethnic Soldiers: State Security in Divided States, Harmondsworth: Penguin.

Evans, P.B., 1992. The State as Problem and Solution. In S. Haggard \& R. R. Kauffman, eds. The Politics of Economic Adjustment. Princeton, New Jersey: Princeton University Press, pp. 139-181.

Farwell, B., 1984. The Gurkhas, London: Penguin Books.

Fisher, F.., 2001. Fluid Boundaries: Forming and Transforming Indentity in Nepal, New York: Columbia University Press.

Fisher, W.., 2009. Nationalism and the Janajati. Himal South Asian, (December). Available at: http://www.himalmag.com/component/content/article/4228-nationalism-and-the-janajati.html (accessed December 20, 20110.

Fitzpatrick, I.C., 2011. Cardamom and Class: A Limbu Village and its Extensions in East Nepal, Kathmandu: Vajra Publications.

Fonning, A., 1987. Lepcha, my vanishing tribe, New Delhi: Sterling Publishers.

Forbes, A.A., 1999. Mapping Power: Disputing Claims to Kipat Lands in Northeastern Nepal. Amercian Ethnologist, 26(1), pp.114-138. 
Fumagalli, M., 2007. Framing Ethnic Minority Mobilisation in Central Asia: The Case of Uzbeks in Kyrgyzstan and Tajikistan. Europe-Asia Studies, 59(4), pp.567-590.

Gaenszle, M., 2002. Contesting the "Great" Traditios: Remakings of the Kiranti Past. In A. Harneit-Sievers, ed. A Place in the World: New Local Historiographies from Africa and South Asia. Leiden: Brill, pp. 331-346.

Ganguly-Scarse, S., 1999. A Bitter Pill or Sweet Nectar? Contradictory Attitudes of Salaried Workers to Economic Liberalization in India. Development and Society, 28(2), pp.259-283.

Gellner, D., 2007. From Group Rights to Individual Rights and back-Nepalese Struggle overCulture and Equality. In J. . Cowan, M.-B. Dembour, \& R. Wilson, eds. Culture and Rights:Anthropological Perspectives. Cambridge: Cambridge University Press, pp. 177-201.

Gerth, H.. \& Mills, C.. eds., 1948. From Max Weber: Essays in Sociology, Oxon: Routledge.

Giuliano, E., 2000. Who Determines the Self in the Politics of Self-Determination? Identity and Preference Formation in Tatarstan's Nationalist Mobilization. Comparative Politics, 32(3), pp.295-316.

Glazer, N. \& Moynihan, D.P., 1975. Ethnicity: Theory and Experience, Cambridge: Harvard University Press.

Goffman, I., 1974. Frame Analysis: An Essay on the Organization of Experience, Cambridge: Harvard University Press.

Golay, B., 2006. Rethinking Gorkha Identity: Outside the Imperium of Discourse, Hegemony and History. Peace and Democracy in South Asia, 2(1/2), pp.23-49.

Guha Roy, S., 2003. Demographic Patterns and Migration in West Bengal, West Bengal Human Development Report.

Gupta, R., 1975. Sikkim: The Merger with India. Asian Survey, 15(9), pp.786-798.

Gupta, R.D., 1986. From peasants and tribesmen to plantation workers: colonial capitalism, reproduction labour power and proletarianisation in North East India, 1850s to 1947. Economic and Political Weekly, 22(4), pp.2-10.

Gupta, R.D., 1992. Plantation Labour in Colonial India. In V. E. Daniel, H. Bernstein, \& T. Brass, eds. Plantations, Proletarians and Peasants in Colonial Asia. London: Frank Cass, p. Plantations, Proletarians and Peasants in Colonial Asia.

Gurung, H., 1997. State and Society in Nepal. In D. Gellner, J. Pfaff-Czarnecka, \& J. Whelpton, eds. Nationalism and Ethnicity in a Hindu Kingdom. Amsterdam: Harwood Academic Publishers.

Gurung, H., Gurung, Y. \& Chidi, C.L., 2006. Nepal Atlas of Ethnic and Caste Groups, Kathmandu: National Foundation for Development of Indigenous Nationalities. 
Gurung, S., 2010. Sikkim: Ethnicity and Political Dynamics, A Triadic Perspective, New Delhi: Kunal Books.

Hacchethu, K., 2003. Democracy and Nationalism-Interface between State and Ethnicity in Nepal. Contributions to Nepalese Studies, 30(2), pp.217-252.

Hachhethu, K., 2003. Democracy and Nationalism interface between state and ethnicity in Nepal. Contribution to Nepalese Studies, 30(2), pp.217-252.

Hachhethu, K., 2009. State Building in Nepal: Creating a Functional State, Kathmandu: Enabling State Programme.

Hachhethu, K., 2008. The Second Transformation of Nepali Political Parties. In L. R. Baral, ed. Nepal: New Frontiers of Restructuring of State. New Delhi: Adroit Publishers, pp. 125-143.

Hacking, I., 2006. Making Up People. London Review of Books, 28(16), pp.23-26.

Hangen, S., 2007. Creating a "New Nepal": The Ethnic Dimension.

Hangen, S., 2010. The Rise of Ethnic Politics in Nepal Special Nepal Edition., Oxon: Routledge.

Hiltz, J., 2003. Constructing Sikkimese National Identity in the 1960s and 1970s. Bulletin of Tibetology, 39, pp.67-83.

Hiltz, J., 2011. I May Be Branded as Communal but Look at Things from my Angle': Palden Thondup Namgyal and the Preservation of the Bhutia-Lepcha Ethos in the Buddhist Kingdom of Sikkim. In A. Balicki-Denjongpa \& A. McKay, eds. Buddhist Himalaya: Studies in Religion, History and Culture, Proceedings of the Golden Jubilee Conference of the Namgyal Institute of Tibetology. Gangtok: Namgyal Institute of Technology, pp. 113-126.

Hobsbawm, E. \& Ranger, T., 1983. The Invention of Tradition, Cambridge: Cambridge University Press.

Horowitz, D.L., 2009. Cultural Movements and Ethnic Change. The ANNALS of the American Academy of Social and Political Science, 433(1), pp.6-18.

Hussain, I., 2003. Soldiers and Settlers: The Recruitment of the Gorkhas. In A. C. Sinha \& T.B. Subba, eds. The Nepalis in Northeast India. New Delhi: Indus Publishing Company, pp. 124-147.

Hutt, M., 1997. Being Nepali without Nepal: Reflections on a South Asian Diaspora. In D. Gellner, J. Pfaff-Czarnecka, \& J. Whelpton, eds. Nationalism and Ethnicity in a Hindu Kingdom. Amsterdam: Harwood Academic Publishers, pp. 101-144.

Hutt, M., 1998. Going to Mugalan: Nepali Literary Representations of Migration to India and Bhutan. South Asia Research, 18(2), pp.195-214.

Hutt, M. ed., 2004. Himalayan “People”s War': Nepal's Maoist Rebellion, Bloomington: Indian University Press. 
Hutt, M., 1991. Himalayan Voices: An Introduction to Modern Nepali Literature, Berkeley: University of California Press.

Hutt, M., 1997. Modern Literary Nepali: An Introductory Reader, New Delhi: Oxford University Press.

Hutt, M., 1988. Nepali, a national language and its literature, New Delhi and London: Sterling Publishers.

Hutt, M., 2005. The Bhutanese refugees: between verification, repatriation and royal realpolitik. Peace and Democracy in South Asia, 1(1), pp.44-56.

Hutt, M., 2003. Unbecoming Citizens: Culture, Nationhood, and the Flight of Refugees from Bhutan, Oxford: Oxford University Press.

Jamil, I. \& Dangal, R., 2009. The State of Bureaucratic Representativeness and Administrative Culture in Nepal. Contemporary South Asia, 17(2), pp.193-211.

Jessop, B., 2007. State Power, Cambridge: Polity Press..

Jones, R.L., 1976. Sanskritization in Eastern Nepal. Ethnology, 15(1), pp.63-75.

Joseph, M.C., 1999. Ethnic Conflict in Bhutan, New Delhi: Nirala Publications.

Joshi, B.L. \& Rose, L.E., 1966. Democratic Innovations in Nepal: A Case Study of Political Acculturation, Berkeley: University of California Press.

Junn, J., 2006. When Does Ethnicity Have Political Consequences? In T. Lee, S. K. Ramakrishnana, \& R. Ramirez, eds. Transforming Politics, Transforming America: The Political and Civic Incorporation of Immigrants in the United States. Charlottsberg: University of Virginia Press, pp. 33-48.

Kaboolian, L., 1998. The New Public Management: Challenging the Boundaries of the Management vs. Administration Debate. Public Administration Review, 58(3), pp.189-193.

Kapila, K., 2008. The measure of a tribe: The cultural politics of constitutional reclassification in North India. Journal of Royal Anthropological Institute, 14, pp.117-134.

Kazi, J.N., 2009. Sikkim for Sikkimese: Distinct Identity within the Union, Gangtok: Hill Media Publications.

Khawas, V., 2012. Agriculture in the Sikkim Himalayas: A Geographical Note. In M. Yasin \& D. Chhetri, eds. Politics, Society and Development: Insights from Sikkim. New Delhi: Kalpaz Publications, pp. 187-202.

Khawas, V., 2010. Reflection on Climate Change Leaders from the Himalayas: Livelihoods and Peoples Perceptions, New Delhi: Leadership for Environment and Development-India. Available at: http://www.leadindia.org/beta/gallery/Livelihoods_Peoples_Perception.pdf. (accessed: 20/07/2013). 
Kharel, M.. \& Basnet, L., 2008. The Khasas of Sikkim, Gangtok: Akhil Sikkim Chhettri Bahun Kalyan Sangh.

Kingsbury, B., 1998. "Indigenous Peoples" in International Law: A Constructivist Approach to the Asian Controversy. The American Journal of International Law, 92(3), pp.414-457.

Kohli, A., 1997. Can Democracies Accomodate Ethnic Nationalism? Rise and Decline of Self-Determination Movements in India. The Journal of Asian Studies, 56(2), pp.325-344.

Kumar, D., 2010. Electoral Violence and Volatility in Nepal, Kathmandu: Vajra.

Kumar, D., 2008. Obstacle to Local Leadership and Democracy in Nepal. In D. Gellner \& K. Hachhethu, eds. Local Democracy in South Asia: Microprocesses of Democratization in Nepal and its Neighbours. Los Angeles: Sage, pp. 25-44.

Kymlicka, W., 2007. The Internationalization of Minority Rights. International Journal of Constitutional Law, 6(1), pp.1-32.

Lacina, B., 2009. The Problem of Political Stability in Northeast India: Local Ethnic Autocracy and the Rule of Law. Asian Survey, 49(6 (November/December)), pp.998-1020.

Laitin, D., 1999. Why Ethnicity and "pork" Tend To Go Together. Paper presented at the Conference of Ethnic Politics and Democratic Stability at the University of Chicago

Lama, B., 2008. The story of Darjeeling: the land of the Indian Gorkha, Kurseong: Nilima Yonzone Lama Publications.

Lama, M.. ed., 1994. Sikkim: Society, Polity, Economy, Environment, New Delhi: Indus Publishing Company.

Lama, M.P., 2001. Sikkim Human Development Report, New Delhi: Government of Sikkim. Available at: http://planningcommission.nic.in/plans/stateplan/sdr_pdf/shdr_sikkim01.pdf.

Laswell, H.., 1927. The Theory of Political Propaganda. American Political Science Review, 21(3), pp.627-631.

Lawoti, M. ed., 2007. Contentious Politics and Democratization in Nepal, New Delhi: Sage.

Lecomte-Tilouine, M., 2004. Ethnic demands within Maoism: Questions of Magar Territorial Autonomy, Nationality and Class. In M. Hutt, ed. The Himalayan People's War. Bloomington: Indiana University Press, pp. 112-135.

Lecomte-Tilouine, M. \& Dollfus, P. eds., 2003. Ethnic Revival and Religious Turmoil: Identities and Representations in the Himalayas, New Delhi: Oxford University Press.

Leftwich, A., 1995. Bringing Politics Back In: Towards a Model of the Developmental State. Journal of Development Studies, 31(3), pp.400-427. 
Lelyveld, D., 665. Colonial Knowledge and the Fate of Hindustani. Comparative Studies in Society and History, , 35(4), p.1993.

Lemarchand, R. \& Legg, K., 1972. Political Clientalism and Development: A Preliminary Analysis. Comparative Politics, 4(2), pp.149-178.

Ling, T., 1985. Max Weber and the relation of religious to social change:: some considerations from Nepal and Sikkim. In A. Buss, ed. Max Weber in Asian Studie. Leiden: Brill, pp. 115-128.

Little, K., 2008. Lepcha Narratives Of Thier Threathened Sacred Landscapes. Transforming Cultures eJournal, 3(1), pp.227-255.

Lohani, M.P., 1973. The Monarchy in Nepal: an indispensible political institution, Kathmandu: Ministry of Communications: Government of Nepal.

Madsen, S.T., Nielsen, K.B. \& Skoda, U., 2011. Trysts with Democracy: Political Practice in South Asia, London: Anthem Press.

Maharjan, M.H., 2012. Vote for Prashant Tamang: Representations of an Indian Idol in the Nepali print media and the retreat of multiculturalism . European Bulletin of Himalayan Research , (41), pp.30-57.

Malesevic, S., 2002. Rational Choice Theory and the Sociology of Ethnic Relations: A critique. Ethnic and Racial Studies, 25(2), pp.193-212.

McDuie-Ra, D., 2011. The dilemmas of pro-development actors: viewing state, ethnic minority relations and intra-ethnic dynamics through contentious development projects'. Asian Ethnicity, 12(1), pp.77-100.

Metcalf, B.D. \& Metcalf, T.R., 2006. A Concise History of Modern India Second., Cambridge: Cambridge University Press.

Michaels, A., 1997. The King and the Cow. In D. Gellner, J. Pfaff-Czarnecka, \& J. Whelpton, eds. Nationalism and Ethnicity in a Hindu Kingdom: The Politics of Culture in Contemporary Nepal. Amsterdam: Harwood Academic Publishers, pp. 79-100.

Michelutti, L., 2004. "We (Yadavs) are a caste of politicians": Caste and modern politics in a north Indian town. Contributions to Indian Sociology, 38(1-2), pp.43-71.

Michelutti, L.,2014. "The vernacularization of democracy:political participation and popular politics in North India. Journal of the Royal Anthropological Institute, 13,pp.640-656.

Middleton, T., 2011. Across the interface of state ethnography: Rethinking ethnology and its subjects in multicultural India. American Ethnologist, 38(2), pp.249-266.

Middleton, T., 2013. States of difference: Refiguring ethnicity and its "crisis" at India's borders. Political Geography, 35, pp.14-24. 
Migdal, J., 2001. State in Society: Studying How States and Societies Constitute and Transform Each Other, Cambridge: Cambridge University Press.

Mishra, C., 2007. Essays on the Sociology of Nepal, Kathmandu: FinePrint Books.

Mitra, S.K., 1992. Power, Protest and Participation: Local Elites and the Politics of Development in India, London: Routledge.

Mitra, S.K., 1991. Room to Maneuver in the middle: Local Elites, Political Action and the State in India. World Politics, 43(3), pp.390-413.

Mitra, S.K., 1995. The Rational Politics of Cultural Nationalism: Sub-national Movements of South Asia in a Comparative Perspective. British Journal of Political Science, 25(1), pp.57-77.

Moktan, R., 2004. Sikkim: Darjeeling Compendium of Documents, Darjeeling: R.Moktan.

Mosse, D., 1999. Responding to Subordination: Identity and change among South Indian Untouchables Castes. In J. R. Campbell \& A. Rew, eds. Identity and Affect: Experiences of Identity in a globalizing wrold. London: Pluto Press, pp. 64-104..

Mukhim,P.,2011.Northeast The Telegraph. Available at: http://www.telegraphindia.com/1111017/jsp/northeast/story_14623761.jsp.

Nagel, Joan, 1995. American Indian Ethnic Renewal: Politics and the Resurgence of Identity. American Sociological Review, 60(6), pp.947-965.

Nair, A., 1985. Ethnicity, Identity and Integration. In A. Pant \& S. . Gupta, eds. Multi-Ethnicity and National Integration. Allahabad: Vohra Publishers and Distributors, pp. 100-115.

Nakane, C., 1966. A Plural Society in Sikkim: A Study of the Interrelations of Lepchas, Bhotias and Nepalis. In C. V. Furer-Haimendorf, ed. Caste and Kin in Nepal, India and Ceylon: Anthropological studies in Hindu-Buddhist Contact Zones. Bombay: Asia Publishing House, pp. 213-263.

Nath, L., 2005. Migrants in Flight: Conflict-Induced Internal Displacement of Nepalis in Northeast India. Peace and Democracy in South Asia, 1(1), pp.56-72.

Nielsen, F., 1985. Towards a Theory of Ethnic Solidarity in Modern Societies. American Sociological Review, 50(2), pp.133-149.

Nordholt, H.., 2003. Renegotiating boundaries: Access, agency and identity in post-Soeharto Indonesia.Bijdragen tot de Taal-, Land-en Volkenkunde, 159(4), pp.550-589.

O’Maley, L.L.S., 1907. Darjeeling District Gazetteer 1st ed., Calcutta: Bengal Secretariat Book Depot.

Onta, P., 1996. The Politics of Bravery: A History of Nepali Nationalism. University of Pennsylvania.

Onta, P.,2006. The growth of the adivasi janajati movement in Nepal after 1990: The non-political institutional agents. Studies in Nepali History and Society, 11(2), pp.303-354. 
Paasi, A., 1998. Boundaries as Social Processes: Territoriality in the World of Flows. Geopolitics, 3(1), 69-88.

Pandey, M.R., 1973. How Jung Bahadur established Rana rule in Nepal. Contributions to Nepalese Studies, 1(1), pp.50-63.

Parajuli, K., January-February. The long, long Lhotshampa exile. Himal Magazine, 18(4). Available at:http://www.himalmag.com/component/content/article/1631-the-long-long-lhotshampa-exile.ht ml (accessed: 31/05/2013).

Pemble, J., 2009. Forgetting and Remembering Britain's Gurkha War. Asian Affairs, 40(3), pp.361-376.

Pfaff-Czarnecka, 1991. State and Community:Changing Relations of Production after the Unification of Nepal. In H. J. Claessen \& P. van de Velde, eds. Early State Economies. New Brunswick: Transaction Publishers.

Pfaff-Czarnecka, J., 1997. Vestiges and Visions: Cultural Change in the Process of Nation-Building in Nepal. In D. Gellner, J. Pfaff-Czarnecka, \& J. Whelpton, eds. Nationalism and Ethnicity in a Hindu Kingdom. Amsterdam: Harwood Academic Publishers, pp. 419-470.

Phadnis, U., 1980. Ethnic Dimension of Sikkimese Politics: the 1979 Elections. Asian Survey, 20(12), pp.1236-1252.

Phadnis, U. \& Ganguly, R., 1989. Ethnicity and Nation-building in South Asia 1st ed., New Delhi: Sage.

Pieterse, J.N. \& McAllister, P., 1996. Varieties of Ethnic Politics and Ethnic Discourse. In P. Wilmsen, ed. The Politics of Difference: Ethnic Premises in a World of Power. Chicago and London: The University of Chicago Press, pp. 25-44.

Poddar, P. \& Prasad, A. eds., 2009. Gorkhas Imagined: Indra Bahadur Rai in Translation, Kalimpong: Mukti Prakashan.

Polletta, F. \& Jasper, J.M., 2001. Collective Identity and Social Movements. Annual Review of Sociology, 27, pp.283-305.

Poudyal, M.P., 1984. Public Administration and Nation-Building in Nepal, New Delhi: NBO Publishers' Distributors.

Pradhan, K., 1984. A History of Nepali Literature, Delhi: Sahitya Akademi.

Pradhan, K., 1991. The Gorkha Conquests: The Process and Consequences of the Unification of Nepal with particular reference to Eastern Nepal, Calcutta: Oxford University Press.

Pradhan, R., 2002. Ethnicity, Caste and a Pluralist Society. In K. M. Dixit \& S. Ramachandran, eds. State of Nepal. Kathmandu: Himal Books, pp. 1-22. 
Rai, I.B., 1994. Indian Nepali Nationalism and Nepali Poetry. Journal of South Asian Literature, 29(1), pp.149-154.

Rai,J.,.Sikkim: Small Wonder. Times of India. Available at: http://indiatoday.intoday.in/story/sikkim+small+wonder/1/62350.html (accessed 13/03/2012).

Rai, S.K., 2008. Kirat Khambu Rais of Sikkim and Eastern Himalayas, Gangtok, Sikkim: Shivika Enterprise.

Ram, M.K., 2007. Movement for Telangan State: Struggle for Autonomy. Economic and Political Weekly, 42(2), pp.13-19.

Regmi, M.., 1984. The State and Economic Surplus: Production, Trade and Resource Mobilization in the Early 19th Century, Varanasi: Nath Publishing House.

Riaz, A. \& Basu, S., Paradise Lost? State Failure in Nepal, Lanham: Lexington Books.

Rose, L.E., 1978. Modernizing a Traditional Administrative System: Sikkim 1890-1973. In F. J. Fisher, ed. Himalayan Anthropology: The Indo-Tibetan Interface. Hague: Mouton, pp. 205-226.

Rose, L.E., 1971. Nepal: Strategy for Survival, Berkley: University of California Press.

Royce, A.P., 1982. Ethnic Identity: Strategies of Diversity, Bloomington: Indiana University Press.

Rudd, A.E., 1999. Embedded Bengal: The Case for Politics. Forum for Development Studies, 2, pp.235-259.

Rudolph, J., 2006. Politics and Ethnicity, Houndsmills: Palgrave Macmillan.

Sagant, P., 1996. The Dozing Shaman: The Limbus of Eastern Nepal, Oxford: Oxford University Press.

De Sales, A., 2000. The Kham Magar Country, Nepal: Between ethnic claims and Maoism. European Bulletin of Himalayan Research, (19), pp.41-71.

Samanta, A.K., 2003. Gorkhaland Movement: A Study in Ethnic Separatism, New Delhi: A.P.H Publishing.

Sambanis, N., 2001b. Do Ethnic and Non-Ethnic Civil Wars Have the Same Causes? A Theoretical and Empirical Inquiry (Part 1). Journal of Conflict Resolution, 45(3), pp.259-282.

Sarkar, K. \& Bhowmik, S.K., 1999. Trade Unions and Women Workers in Tea Plantations. Economic and Political Weekly, 33(52), pp.L50-L52.

Sarkar, R. \& Lama, M. eds., 1986. Tea plantation workers in the eastern Himalayas- a study on wages, employment and living standards, Delhi: Atma Ram and Sons.

Sarkar, S., 2008. Dress, Difference and Dissent in the Darjeeling Hills. South Asian Citizen's Web. Available at: http://www.sacw.net/article442.html [Accessed September 9, 2012]. 
Van Schendel, W., 2011. The Dangers of Belonging: Tribes, Indigenous Peoples and Homelands in South Asia. In D. J. Rycroft \& S. Dasgupta, eds. The Politics of Belonging in India: Becoming Adivasi. Oxon: Routledge.

Van Schendel, W.\& Maaker D.E., Asian Borderlands: Introducing their permeability, strategic uses and meanings. Journal of Borderland Studies, 29(1),pp:3-9.

Schlemmer, G., 2003. New Past for the Sake of a Better Future: Re-inventing the history of the Kiranti in East Nepal. European Bulletin of Himalayan Research, 25/26, pp.119-144.

Schlemmer, G., 2010. Rai, Khambu, Subba, Kirat etc.: Ethnic labels or political and land tenure categories? Logics of identification of an ensemble of population in Nepal. In C. Culas \& F. Robinne, eds. Interethnic Dynamics in Asia. Ethnonyms, Considering the Other though ethnonyms, territories and rituals. Routledge Contemporary Asia Series. London: Routledge, pp. $42-60$.

Scott, J., 1969. Corruption, Machine Politics, and Political Change. American Political Science Association, 63(4), pp.1142-1158.

Seddon, D., Adhikari, J. \& Gurung, G., 2002. Foreign Labor Migration and the Remittance Economy of Nepal. Critical Asian Studies, pp.19-40.

Sengupta, N., 1988. Reappraising Tribal Movements II- Legitimisation and Spread. Economic and Political Weekly, 23(20), pp.1003-1005.

Sharma, Khemraj, 1997. Socio-economic life of Cinchona Plantation Workers in India, Dibrugarh: N.L.Publishers.

Sharma, Kishor, 2006. The political economy of civil war in Nepal. World Development, 34(7), pp.1237-1253.

Sharma, P., 2008. Unraveling the Mosaic: Spatial Aspects of Ethnicity in Nepal, Lalitpur, Nepal: Himal Books.

Sharma, R.P., 1997. Nation-Building, Multi-Ethnicity and the Hindu State. In D. Gellner, J. Pfaff-Czarnecka, \& J. Whelpton, eds. Nationalism and Ethnicity in a Hindu Kingdom. Amsterdam: Harwood Academic Publishers, pp. 471-494.

Shimray, U.A., 2004. Socio-Politcal Unrest in the region called North-east India. Economic and Political Weekly, 39(42), pp.4637-4643.

Shneiderman, S., 2009. Ethnic (P)reservation: Comparing Thangmi Ethnic Activism in Nepal and India. In D. Gellner, ed. Ethnic Activism and Civil Society in South Asia. London: Sage, pp. $115-141$.

Shneiderman, S. \& Middleton, T., 2008. Reservations, Federalism and the Politics of Recognition in Nepal. Economic and Political Weekly, 43(19), pp.39-45. 
Shneiderman, S. \& Turin, M., 2006. Seeking the Tribe: Ethnopolitics in Darjeeling and Sikkim. Himal South Asian, (March-April), pp.54-58.

Shneiderman, S., 2015. Rituals of Ethnicity: Thangmi Identities between Nepal and India, Philadelphia: University of Pennsylvania Press.

Shore, C., 2002. Introduction: Towards an Anthropology of Elites. In C. Shore \& S. Nugent, eds. Elite Cultures: Anthropological Perspectives. London: Routledge, pp. 1-21.

Shrestha, B.G., Ritual and Identity in the Diaspora: The Newars of Sikkim. Bulletin of Tibetology, 41(1), pp.21-54.

Shresthova, S., 2010. Under India's big umbrella? Bollywood dance in Nepal. South Asian Popular Culture, 3(8), pp.309-323.

Sinha, A.C, 2007. The Indians of Nepal origin and security of North-east India. In T.B. Subba \& A. C. Sinha, eds. The Nepalis in Northeast India: A Community in Search of an Indian Identity. New Delhi: Indus Publishing Company, pp. 360-377.

Sinha, A.C. et al., 2005. Ethnographic Report on selected communities of Sikkim,

Sinha, A.C., 2008. Lhotshampa, Madhesi, Nepamul: the deprived of Bhutan , Nepal and India. Himal South Asian. Available at: http://www.himalmag.com/component/content/article/1023-lhotshampa-madhesi-nepamul-the-de prived-of-bhutan-nepal-and-india.html (accessed 21/10/2012).

Sinha, A.C., 2006. Search for Kirat Identity: Trends of De-Sanskritization Among the Nepamul Sikkimese. Peace and Democracy in South Asia, 2(1 and 2), pp.1-22.

Sinha, A.C., 2009. The Politics of Identity Formation in Sikkim. Dialogue. Dialouge, 10(4).

Snow, D. et al., 1986. Framing Alignment Processes, Micromobilization, and Movement Participation. American Sociological Review, 51(4), pp.464-481.

Spencer, J., 2007. Anthropology, Politics and the State, Cambridge: Cambridge University Press.

Srinivas, M.., 1952. Religion and Society among the Coorgs of South India, Oxford: Clarendon.

Subba, D. \& Subba, S., 2003. Learning in our own language: Kirat Yakthung Chumlung develop a Limbu literacy programme in Nepal, Mumbai, India: Asian South Pacific Bureau of Adult Education (ASPBAE).

Subba, J.., 2011. History, Culture and Customs of Sikkim Second., New Delhi: Gyan Publishing House.

Subba, T.B, 2003. Being a Nepali in north-east India: Predicament of a "Privileged Nation". In T.B Subba \& A. . Sinha, eds. The Nepalis in North-east India: A Community in Search of Indian Identity. New Delhi: Indus Publishing Company.

Subba, T.B et al. eds., 2009a. Indian Nepalis: Issues and Perspectives, New Delhi: Concept Publishing Company. 
Subba, T.B et al. eds., 2009b. Indian Nepalis: Issues and Perspectives, Concept Publishing Company: New Delhi.

Subba, T.B, 2002. Nepal and the Indian Nepalis. In K. M. Dixit \& S. Ramachandran, eds. State of Nepal. Kathamandu: Himal Books, pp. 119-136.

Subba, T.B, 1999. Politics of Culture: A study of Three Kirata Communities in the Eastern HImalayas, Hyderabad: Orient Longman.

Subba, T.B., 1992. Ethnicity, state and development: a case study of the Gorkhaland movement in Darjeeling, New Delhi: Vikas Publishing House.

Subba, T.B., 1989. Sociological Consequences of Tourism in Darjeeling. In S. . Singh, ed. Impact of Tourism on Mountain Environment. Meerut: Research India Publications, pp. 305-314.

Thapa, D., 2002. The Maobadi of Nepal. In K. M. Dixit \& S. Ramachandran, eds. The State of Nepal. Kathmandu: Himal Books, pp. 77-99.

Thieme, S., Kollmair, M. \& Muller-Boker, U., 2003. Labour Migration from Far West Nepal to Delhi, India. European Bulletin of Himalayan Research, 24(Spring), pp.82-89.

Tilouine-Lecomte, M. \& Gellner, D., 2004. Regicide and Maoist revolutionary warfare in Nepal: Modern incarnations of a warrior kingdom. Anthropology Today, 20(1), pp.13-19.

Tirkey, P.L., 2005. Tea Plantations in Darjeeling District, India: Geo-ecological and socio-economic impacts in Post-Independence period. Ph.D Thesis. University of Manitoba.

Tiwari, B.N., 2008. Horizontal Inequalities and Violent Conflict in Nepal. Himalaya, 28(1-2), pp.33-48.

Toffin, G., 2006. The Politics of Hinduism and Secularism in Nepal. In P Onta et al., eds. Studies in Nepali History and Society. Kathmandu: Mandala Book Point, pp. 219-239.

Turner, R.L., 1926. A Comparative and Etymological Dictionary of the Nepali Language, London: K.Paul, Trench, Trubner. Available at: A Comparative and Etymological Dictionary of the Nepali Language.

Van, Schendel, W., 2005 a. Spaces of Engagement: How Borderlands, Illicit Flows and Territorial State Interlock. In W. V. Schendel \& I. Abraham, eds. Illicit Flows and Criminal Things: States, Borders and the Other side of Globalisation. Bloomington: Indiana University Press, pp. 38-68.

Vandenhelsken, M., 2011. The Enactment of Tribal Unity at the Periphery of India: The Political Role of a New Form of the Panglhabsol Buddhist Ritual in Sikkim. European Bulletin of Himalayan Research, 38(Spring-Summer), pp.83-118.

Varshney, A., 2003. Nationalism, Ethnic Conflict and Rationality. Perspectives on Politics, 1(1), pp.85-99. 
Wagle, D., 2010. Dakhar still. Himal Magazine. Available at:

http://www.himalmag.com/component/content/article/226-dakhar-still.html (accessed 06.05/2013).

Weeks, J., 1990. The Value of Difference. In J. Rutherford, ed. Identity: Community, Culture, Difference. London: Lawrence and Wishart, pp. 88-100.

Whaites, A., 2008. States in Development: Understanding State-building. Available at: http://tna.europarchive.org/20081212094836/http:/dfid.gov.uk/pubs/files/State-in-DevelopmentWkg-Paper.pdf. (accessed 12/04/2013).

Whelpton, J., 2005. A History of Nepal, Cambridge: Cambridge University Press.

Whelpton, J., 1991. Kings, Soldiers and Priests: Nepalese Politics and the Rise of Jang Bahadur Rana, New Delhi: Manohar.

Whelpton, J., 1997. Political Identity in Nepal: State, Nation and Community. In D. Gellner, J. Pfaff-Czarnecka, \& J. Whelpton, eds. Nationalism and Ethnicity in a Hindu Kingdom. Amsterdam: Harwood Academic Publishers.

Wilson. T. \& Donnan.H., Border and Border Studies. 2012. In T.Wilson, \& H.Doonan, eds. A companion to Border Studies. Oxford:Wiley-Blackwell,pp 1-26.

Wright, S., 1998. The "Politicization" of Culture. Anthropology Today, 14(1), pp.7-15.

Xaxa, V., 1985. Colonial Capitalism and Underdevelopment of North Bengal. Economic and Political Weekly, 20(39), pp.1659-1665.

Xaxa, V., 1999. Tribes as Indigenous People of India. Economic and Political Weekly, 34(51), pp.3589-3595.

Zald, M.N., 1996. Culture, Ideology and Strategic Framing. In D. McAdam, J. D. McCarthy, \& M. N. Zald, eds. Comparative Perspectives on Social Movements: Political Opportunities, Mobilizing Structures, and Cultural Framings. Cambridge: Cambridge University Press, pp. 161-174.

Zappala, G., 1998a. Clientalism,Political Culture and Ethnic Politics in Australia. Australian Journal of Political Science, 33(3), pp.381-397.

\section{Reports and magazines}

Government of Sikkim (GoS). 2006. State Socio-Economic Census. Gangtok: Department of Economics, Statistics, Monitoring and Evaluation, .

Government of West Bengal (GoWB). 2004. West Bengal Human Development Report 2004. Kolkata: Development and Planning Department, GoWB. Available at hdr.undp.org/sites/default/files/india_west_bengal_2004_en.pdf; accessed date [17/03/2013]. 
Comptroller and Auditor General, Sikkim (GoS). 2014. Audit Report on State Finances for the year ended 31 March 2014.

Chaaya. 1998. Sikkimay Nepali Ki NBC ra OBC?. 4 (4 Nov): pp.12-14. 
